Article

\title{
Use of Radial Basis Function Network to Predict Optimum Calcium and Magnesium Levels in Seawater and Application of Pretreated Seawater by Biomineralization as Crucial Tools to Improve Copper Tailings Flocculation
}

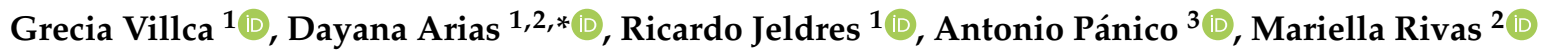 \\ and Luis A. Cisternas $1, * \mathbb{B}$ \\ 1 Departamento de Ingeniería Química y Procesos de Minerales, Universidad de Antofagasta, \\ Av. Universidad de Antofagasta, 02800 Antofagasta, Chile; greciahassel05@gmail.com (G.V.); \\ ricardo.jeldres@uantof.cl (R.J.) \\ 2 Departamento de Biotecnología, Facultad de Ciencias del Mar y Recursos Biológicos (FACIMAR), \\ Universidad de Antofagasta, Av. Universidad de Antofagasta, 02800 Antofagasta, Chile; \\ mariella.rivas@uantof.cl \\ 3 Telematic University Pegaso, Piazza Trieste e Trento 48, 80132 Naples, Italy; antonio.panico@unipegaso.it \\ * Correspondence: dayana.arias@uantof.cl (D.A.); luis.cisternas@uantof.cl (L.A.C.)
}

Received: 29 May 2020; Accepted: 22 July 2020; Published: 30 July 2020

check for updates

\begin{abstract}
The combined use of the Radial Basis Function Network (RBFN) model with pretreated seawater by biomineralization (BSw) was investigated as an approach to improve copper tailings flocculation for mining purposes. The RBFN was used to set the optimal ranges of $\mathrm{Ca}^{2+}$ and $\mathrm{Mg}^{2+}$ concentration at different $\mathrm{Ph}$ in artificial seawater to optimize the performance of the mine tailings sedimentation process. The RBFN was developed by considering $\mathrm{Ca}^{2+}$ and $\mathrm{Mg}^{2+}$ concentration as well as $\mathrm{pH}$ as input variables, and mine tailings settling rate (Sr) and residual water turbidity $(\mathrm{T})$ as output variables. The optimal ranges of $\mathrm{Ca}^{2+}$ and $\mathrm{Mg}^{2+}$ concentration were found, respectively: (i) 169-338 and 0-130 mg. $\mathrm{L}^{-1}$ at $\mathrm{pH} 9.3$; (ii) $0-21$ and $400-741 \mathrm{mg} \cdot \mathrm{L}^{-1}$ at $\mathrm{pH} 10.5$; (iii) $377-418$ and $703-849 \mathrm{mg} \cdot \mathrm{L}^{-1}$ at $\mathrm{pH}$ 11.5. The settling performance predicted by the RBFN was compared with that measured in raw seawater $(\mathrm{Sw})$, chemically pretreated seawater (CHSw), BSw, and tap water (Tw). The results highlighted that the RBFN model is greatly useful to predict the settling performance in CHSw. On the other hand, the highest Sr values (i.e., 5.4, 5.7, and $5.4 \mathrm{~m} \cdot \mathrm{h}^{-1}$ ) were reached independently of $\mathrm{pH}$ when $\mathrm{BSw}$ was used as a separation medium for the sedimentation process.
\end{abstract}

Keywords: calcium; magnesium; Radial Basis Function Network (RBFN); settling rate; turbidity; biomineralization; mine tailings; water quality

\section{Introduction}

Copper $(\mathrm{Cu})$ is the main product of the Chilean mining industry. $\mathrm{Cu}$ is usually found in the form of sulfide ores and is processed using a pyrometallurgical method, which involves the following operations: (1) ore extraction, (2) mineral processing, (3) smelting, and (4) refining. Specifically, mineral processing includes comminution, the froth flotation process to recover $\mathrm{Cu}$ from sulfide ores, and dewatering to recover and recycle water from concentrates and tailings [1].

The progressive depletion of high-grade ores in the near future will constrain mining factories to process a higher amount of rock to keep stable the production of valuable minerals, thus, 
requiring progressively higher volumes of water. Therefore, a further increase in water demand from the mining sector might be solely fulfilled by using seawater [2,3].

The use of raw seawater causes various operational problems [4]; for example, flotation operations affect bubble stability, activation of minerals, and pulp rheology, among others. There are several studies and reviews about the use of raw seawater directly in flotation processes [5-10]. A review of these studies is outside of the objective of this manuscript. However, another effect in mining operations includes low tailings thickening efficiency when operating under highly alkaline conditions. Specifically, $\mathrm{Ca}^{2+}$ and $\mathrm{Mg}^{2+}$ ions have a substantial effect on the shielding of electric charges [11]; hence, they can more intensely reduce the conformation of polyelectrolytes and lower flocculation efficiency. However, this depends on their concentration in solution, flocculant management, and mineralogy [12]. For example, Witham et al. [13] found that in calcite suspensions, $\mathrm{Ca}^{2+}$ and $\mathrm{Mg}^{2+}$ ions limited sedimentation rates at high polymer dosages. Moreover, their effect was hidden when the mixing conditions during flocculation were particularly intense. On the other hand, Lee et al. [14] pointed out that low levels of $\mathrm{Ca}^{2+}$ and $\mathrm{Mg}^{2+}$ could improve polymer adsorption and increase the size of kaolinite flocs when anionic polyacrylamides are added as flocculants.

The interest in the copper industry is to be able to operate the concentration stages at $\mathrm{pH}$ above 10.5, to promote the pyrite depression in flotation stages. However, this alkaline condition induces the formation of $\mathrm{Mg}^{2+}$ solid complexes, which are insoluble in the medium. A recent study of Ramos et al. [15] showed that these complexes disable the active sites of the flocculant, thus, reducing its ability to form hydrogen bonds and, consequently, causing a drop in the density and size of flocs. The occurrence of such events is responsible for the low sedimentation rates at $\mathrm{pH}$ higher than 10.3. Recently, Jeldres et al. [16] reduced the $\mathrm{Mg}^{2+}$ concentration in seawater by adding lime and filtering the solid complexes. Such water was evaluated as a medium in tailings flocculation, finding out that this method could improve the performance of thickeners. The authors obtained a considerable increase in the sedimentation rate of mineral tailings at $\mathrm{pH} 11$, reaching values that even exceeded the performance obtained at natural $\mathrm{pH}$, which represents the most common current operating condition.

Based on this background, it is evident that divalent cations in seawater affect the performance of the sedimentation process. Therefore, partial desalination of seawater aimed at reducing the concentration of $\mathrm{Ca}^{2+}$ and $\mathrm{Mg}^{2+}$ could be useful to increase settling efficiency. Cruz et al. [17] exhibited that lowering the concentration of $\mathrm{Ca}^{2+}$ and $\mathrm{Mg}^{2+}$ ions by using carbon dioxide gas and a sodium hydroxide solution, improved the flocculation of clay-based tailings. Moreover, Arias et al. [18] proposed a biotechnological treatment to remove divalent ions and obtain pretreated seawater by biomineralization by using a fluidized bed bioreactor (FBB) inoculated with halotolerant ureolytic strain Bacillus subtilis LN8B. Specifically, the process used to obtain pretreated seawater by biomineralization is conducted by ureolytic bacteria capable of forming different crystalline elements from seawater through microbial-induced carbonate precipitation (MICP) [18]. Both studies have shown substantial improvements in tailings flocculation; however, no study has quantified the impact of the synergy concentration of these divalent ions under highly alkaline conditions. Such information is essential to know the optimal concentration ranges for both ions, useful for optimizing seawater treatment practice.

Finally, in this paper, a radially based neural network method (RBFN) was used to find the optimal $\mathrm{Ca}^{2+}$ and $\mathrm{Mg}^{2+}$ concentration ranges to obtain the highest sedimentation rate and lowest residual turbidity. The RBFN method consists of an input layer, hidden layer, and an output layer, with the activation function of the hidden units being radial basis functions. To model and optimize the process with a reasonable number of experiments, a proper experimental plan was designed according to the RBFN method [19]. Furthermore, the desalination of seawater was carried out biologically and chemically through the replication of research from Arias et al. [18] and Cruz et al. [1], respectively. 


\section{Materials and Methods}

\subsection{Artificial Mine Tailings}

The artificial mining tailings used for sedimentation process tests were prepared by mixing $80 \%$ $\mathrm{w} / \mathrm{w}$ quartz, $\left(\mathrm{SiO}_{2}\right.$, Donde Capo Industry, Ñuñoa, Chile, density $\left.=2.67 \mathrm{~g} \cdot \mathrm{cm}^{-3}\right)$ with $20 \% \mathrm{w} / \mathrm{w} \mathrm{kaolinite}$ $\left(\mathrm{Al}_{2} \mathrm{Si}_{2} \mathrm{O}_{5}(\mathrm{OH})_{4}\right.$, Ward Science, Henrietta, NY, USA, density $\left.=2.50 \mathrm{~g} \cdot \mathrm{cm}^{-3}\right)$. Both minerals were sieved with ASTM sieves in sizes lower than $75 \mu \mathrm{m}$. The composition of the mixture was analyzed by X-Ray Diffraction (XRD) using a diffractometer (Siemens D5000, Madison, WI, USA), and the relative abundances are reported in Table 1. Quartz purity was 95.3\%, whereas kaolinite was 98.4\%.

Table 1. Composition of the mixture of quartz and kaolinite used to simulate the artificial mine tailings.

\begin{tabular}{cccc}
\hline Sample & Crystalline Phase & Chemical Composition & Abundance (\%) \\
\hline \multirow{4}{*}{ Quartz } & Quartz & $\mathrm{SiO}_{2}$ & 95.3 \\
& Albite & $\mathrm{NaAlSi}_{3} \mathrm{O}_{8}$ & 0.7 \\
& orthoclase & $\mathrm{KAlSi}_{3} \mathrm{O}_{8}$ & 1.3 \\
& microcline & $\mathrm{KAlSi}_{3} \mathrm{O}_{8}$ & 2.6 \\
\hline \multirow{2}{*}{ Kaolinite } & kaolinite & $\mathrm{Al}_{2} \mathrm{Si}_{2} \mathrm{O}_{5}(\mathrm{OH})_{4}$ & 98.4 \\
& Quartz & $\mathrm{SiO}_{2}$ & 1.6 \\
\hline
\end{tabular}

\subsection{Separation Medium}

\subsubsection{Artificial Seawater}

Artificial seawater (ASw) was obtained by adding different chemical reagents to distilled water following the composition shown in Table 2 and according to Mobin and Sharman [20]. Ultra-high purity chemical reagents were used (Merck, Darmstadt, Germany). Different concentrations of $\mathrm{Ca}^{2+}$ and $\mathrm{Mg}^{2+}$ were set by adequately varying the dosage of $\mathrm{CaCl}_{2}$ and $\mathrm{MgCl}_{2} \times 6 \mathrm{H}_{2} \mathrm{O}$, respectively.

Table 2. Composition of artificial seawater, according to Mobin et al. 2011.

\begin{tabular}{cc}
\hline Component & Concentration $\left(\mathbf{g} \cdot \mathbf{L}^{-\mathbf{1}}\right)$ \\
\hline $\mathrm{NaCl}$ & 24.53 \\
$\mathrm{MgCl}_{2} \cdot 6 \mathrm{H}_{2} \mathrm{O}$ & 11.10 \\
$\mathrm{Na}_{2} \mathrm{SO}_{4}$ & 4.09 \\
$\mathrm{CaCl}_{2}$ & 1.16 \\
$\mathrm{KCl}_{\mathrm{NaHCO}}$ & 0.69 \\
$\mathrm{Narr}_{3}$ & 0.20 \\
$\mathrm{~KB}_{3} \mathrm{BO}_{3}$ & 0.10 \\
\hline
\end{tabular}

\subsubsection{Pretreated Seawater by Biomineralization}

To obtain pretreated seawater by biomineralization (BSw), the concentrations in raw seawater of $\mathrm{Ca}^{2+}$ and $\mathrm{Mg}^{2+}$ were reduced through precipitation by the ureolytic bacterial strain B. subtilis LN8B, isolated from the hypersaline lagoon of the desert of San Pedro de Atacama, Chile [21]. BSw was obtained from bioreactors filled with polyvinyl alcohol and alginate beads (PVA-Alg beads) with entrapped cells of B. subtilis LN8B, according to the experimental system and procedure as described by Arias et al. [18].

\subsubsection{Chemically Pretreated Seawater}

Raw seawater was chemically pretreated (CHSw) to partially remove $\mathrm{Ca}^{2+}$ and $\mathrm{Mg}^{2+}$, using the procedure as described by Cruz et al. [1] with some changes as follows: $1.4 \mathrm{~L}$ of raw seawater was alkalinized by adding $10 \mathrm{M} \mathrm{NaOH}$ to reach a $\mathrm{pH}$ of 10.5 . Afterward, $\mathrm{CO}_{2}$ gas was flushed at 
$3 \mathrm{~L} \min ^{-1}$ for $6 \mathrm{~min}$, and simultaneously, the solution of $\mathrm{NaOH}$ was added for keeping the $\mathrm{pH}$ at 11 . Such treatment resulted in a white-colored solution because of the presence of microcrystals of $\mathrm{Ca}^{2+}$ and $\mathrm{Mg}^{2+}$-based salts, which were removed by a vacuum filtration system equipped with a pump (Vacuubrand industry, Wertheim, Germany) and $12 \mu \mathrm{m}$ filters (Ahlstrom-Munksjö, Helsinki, Finland).

\subsubsection{Tap Water and Raw Seawater}

Tap water (Tw), coming from a reverse osmosis process containing average concentrations of $\mathrm{Ca}^{2+}$ and $\mathrm{Mg}^{2+}$ of $74 \pm 11$ and $23 \pm 5 \mathrm{mg} \cdot \mathrm{L}^{-1}$, respectively, was collected from the aqueduct supplying water to the city of Antofagasta. In contrast, raw seawater (Sw) was obtained from San Jorge Bay of Antofagasta, Chile. Prior to use, raw seawater was filtrated progressively with filters of 10,5 , and $1 \mu \mathrm{m}$ porous size, respectively, to remove the main suspended impurities. The average $\mathrm{Ca}^{2+}$ and $\mathrm{Mg}^{2+}$ concentrations were detected equal to $444 \pm 8$ and $1283 \pm 13 \mathrm{mg} \cdot \mathrm{L}^{-1}$, respectively.

\subsection{Sedimentation Tests}

Sedimentation tests were carried out with artificial tailings $15 \% \mathrm{w} / \mathrm{w}$ suspended in 5 different aqueous media, as follows: ASw, BSw, CHSw, Tw, and Sw. The adopted procedure is schematically summarized in Figure 1:

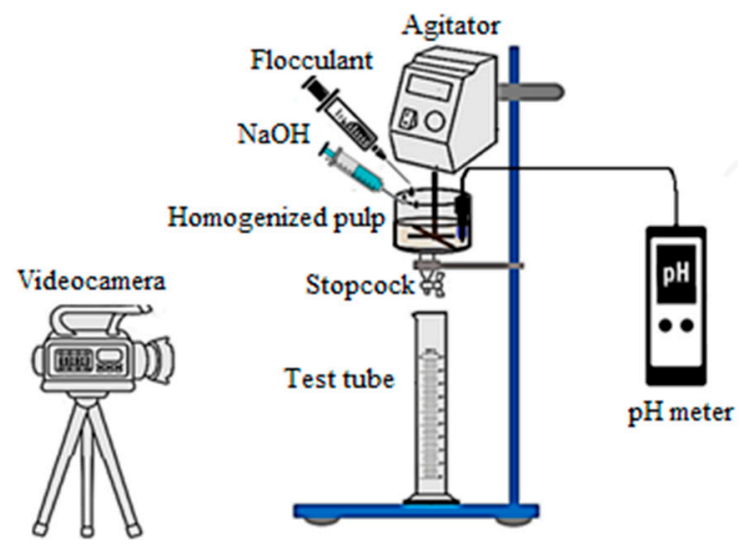

Figure 1. Experimental apparatus.

- Step 1: the mine tailings are added to the aqueous medium by filling a beaker and homogenized by mechanical mixing at $500 \mathrm{rpm}$ for $10 \mathrm{~min}$;

- $\quad$ Step 2: $\mathrm{pH}$ is regulated at a specific set point (i.e., 9.3, 10.5, 11.5) by adding different volumes of $10 \mathrm{M} \mathrm{NaOH}$ solution;

- Step 3: the anionic polyacrylamide flocculant SNF 60430 obtained from Centinela copper mine (Antofagasta, Chile) is added to the aqueous suspension according to a dosage of $20 \mathrm{~g} \cdot \mathrm{ton}^{-1}$ and the mechanical mixer is turned down to $170 \mathrm{rpm}$ and kept constant for $30 \mathrm{~s}$;

- Step 4: the aqueous suspension filling the beaker is poured into a graduated cylinder and kept in static conditions for $1 \mathrm{~h}$;

- Step 5: the volume of supernatant is collected after one hour of sedimentation process and used to measure the turbidity $\mathrm{T}$ (FNU), while for the solid fraction (Cp), it is measured using Equation (1), where $m_{t}$ is the artificial tailing mass, $\rho_{w}$ is water density $\left(1 \mathrm{~g} \cdot \mathrm{cm}^{-3}\right), V i$ is the initial total volume of water needed to form the pulp, and $V s$ is the supernatant volume. The percentage of water recovery $(\% W R)$ is calculated with Equation (2).

$$
C p=\frac{m_{t}}{\rho_{w}(V i-V s)+m_{t}}
$$




$$
\% W R=\frac{V s}{V i} 100 \%
$$

A video camera recorded the sedimentation process that took place in the graduated cylinder. For each sedimentation test, the related video was processed to calculate the following parameter: (i) the mine tailings settling rate, $S r\left(\mathrm{~m} \cdot \mathrm{h}^{-1}\right)$, described by Equation (3).

$$
S r=\frac{\Delta h}{\Delta t}
$$

where $h(\mathrm{~m})$ is the height of the clarified surface water and $t(\mathrm{~h})$ is the time taken by the clarified surface water to reach the minimum height in the graduated cylinder.

\subsection{Experimental Setting}

To maximize the efficiency of the sedimentation process of mine tailings in ASw, it was necessary to find the optimal concentrations of $\mathrm{Ca}^{2+}$ and $\mathrm{Mg}^{2+}$ ions by varying the $\mathrm{pH}$. This study tested operating conditions where the concentration of the $\mathrm{Ca}^{2+}$ and $\mathrm{Mg}^{2+}$ ions was set lower than that typical in seawater. The value of $\mathrm{pH}$ was set higher than 9 due to the flotation process operating condition (the flotation process precedes the sedimentation process). The value of $\mathrm{pH} 9.3$ was used as the initial value because of BSw (the biomineralization process $\mathrm{pH}$ is set to 9.3). The three-level full factorial experimental plan $\left(3^{3}\right.$ experimental tests) was elaborated as reported in Table 3: $\mathrm{Ca}^{2+}$ concentration ranging between 0 and $418.89 \mathrm{mg} \cdot \mathrm{L}^{-1} ; \mathrm{Mg}^{2+}$ concentration ranging between 0 and 1327; finally, $\mathrm{pH}$ ranging between 9.3 and 11.5. A third value, intermediate between the extremes of each interval, was used to complete the $3 \times 3$ matrix of experiments.

Table 3. Parameters and relative values used for setting the experimental plan.

\begin{tabular}{ccccc}
\hline \multirow{2}{*}{ Parameter } & \multirow{2}{*}{ Symbol } & \multicolumn{3}{c}{ Level } \\
\cline { 3 - 5 } & & Low & Intermediate & High \\
\hline $\mathrm{Ca}^{2+}$ concentration $\left(\mathrm{mg} \cdot \mathrm{L}^{-1}\right)$ & $\mathrm{Ca}^{2+}$ & 0 & 209.445 & 418.89 \\
$\mathrm{Mg}^{2+}$ concentration $\left(\mathrm{mg} \cdot \mathrm{L}^{-1}\right)$ & $\mathrm{Mg}^{2+}$ & 0 & 663.5 & 1327 \\
$\mathrm{pH}$ & $\mathrm{pH}$ & 9.3 & 10.5 & 11.5 \\
\hline
\end{tabular}

Finally, a Radial Basis Function Network (RBFN) model [22] was used by considering a three-level factorial design with three independent input variables: $\mathrm{Ca}^{2+}$ concentration, $\mathrm{Mg}^{2+}$ concentration, and $\mathrm{pH}$; two response output variables: mine tailing settling rate (Sr) and supernatant turbidity (T). Numerical simulations were performed using the software of numerical computing MATLAB (version 2009a, MathWorks, Natick, MA, USA).

\subsection{Physical and Chemical Analyses}

$\mathrm{Ca}^{2+}$ and $\mathrm{Mg}^{2+}$ concentrations were measured by using Merck ${ }^{\circledR}$ equipment (cat. No. 1.14815.0001 and 1.00815.0001, respectively; Darmstadt, Germany) and corroborated by Atomic Absorption spectrophotometry analyses, whereas $\mathrm{pH}$ was measured by using a digital $\mathrm{pH}$ meter model HI5222 (Hanna instruments, Woonsocket, RI, USA). Measures of turbidity were performed with turbidimeter model H198713 (Hanna instruments, Woonsocket, RI, USA).

\subsection{Statistical Analysis}

The average values of the experimental data- Sr, T, Cp, \% WR, and the $\mathrm{NaOH}$ consumption-are presented as a function of two factors: type of water and $\mathrm{pH}$. The standard deviations of each set of experiments are represented in the corresponding figure (as bars). Comparisons of the means of $\mathrm{Sr}, \mathrm{T}$, $\mathrm{Cp}, \% \mathrm{WR}$, and the $\mathrm{NaOH}$ consumption were performed to identify statistical significance as a function of water type and $\mathrm{pH}$. Minitab software version 19.1 (State College, PA, USA) through ANOVA general 
linear model tests, was used to conduct the statistical analysis. Comparisons between water types and $\mathrm{pH}$ values were evaluated with the Tukey test. In all investigated cases, the level of significance was set $p<0.05$.

\subsection{Radial Basis Function Network (RBFN)}

Neural networks can represent non-linear assignments of multiple inputs to one or more outputs. These can also be applied to regression problems. The neural network is capable of mapping input variables to continuous values. An important class of neural networks is RBFN. The RBFN consists of an input layer, a hidden layer (Radial Basis Layer), and an output layer (linear layer). The structure of the RBFN is presented in Figure 2, where the inputs are represented by $p^{1}$ and the outputs by $a^{2}$.

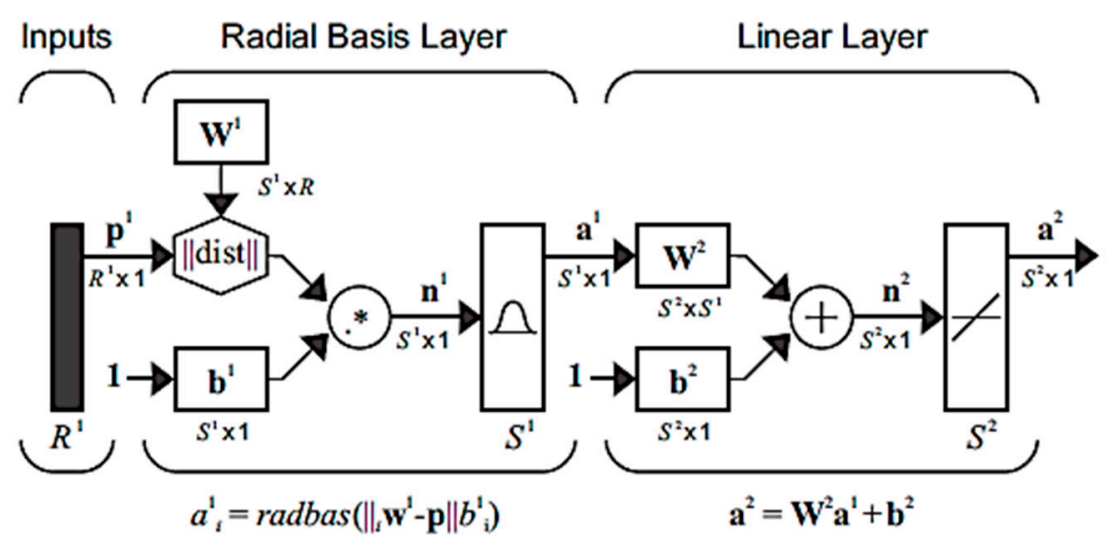

Figure 2. Radial Basis Function Network (RBFN) structure.

In the Radial Basis Layer, the distance between the input vector $p_{i}$ and the rows of the weight $w_{i}{ }^{1}$ are calculated, and then multiplied by the bias $b_{i}$. The net input for the neuron $i\left(n_{i}\right)$ in the Radial Basis Layer is calculated by Equation (4):

$$
n_{i}^{1}=\left\|p_{i}-w_{i}^{1}\right\| b_{i}
$$

where $b_{i}$ is the bias, which is related with standard deviation $\sigma$ with Equation (5).

$$
b_{i}=\frac{1}{\sigma \sqrt{2}}
$$

The transfer function used in the Radial Basis Layer or hidden layer is a Gaussian function, which is commonly used in the neural network community. Equation (6) and Figure 3 represent it.

$$
a^{1}=\exp \left(-\left(n_{i}^{1}\right)^{2}\right)
$$



Figure 3. Gaussian Basis function. 
Finally, the linear layer or the output layer is represented by Equation (7):

$$
a^{2}=w^{2} a^{1}+b^{2}
$$

The performance of the RBFN is evaluated using the mean squared error (MSE). The next equations describe the sequence to calculate the MSE using the RBFN. Let us consider the following training points, in Equation (8):

$$
\left\{p_{1}, t_{1}\right\},\left\{p_{1}, t_{1}\right\}, \ldots \ldots,\left\{p_{Q}, t_{Q}\right\}
$$

The neuron in the hidden layer is calculated by Equations (9) and (10):

$$
\begin{aligned}
& n_{i}{ }^{1}=\left\|p_{i}-w_{i}{ }^{1}\right\| b_{i}{ }^{1} \\
& a^{1}=\exp \left(-\left(n_{i}{ }^{1}\right)^{2}\right)
\end{aligned}
$$

Grouping terms, the following points are obtained in Equation (11):

$$
\left\{a_{1}^{1}, t_{1}\right\},\left\{a_{2}^{1}, t_{2}\right\}, \ldots \ldots,\left\{a_{Q^{1}}^{1} t_{Q}\right\}
$$

Then, the response $a^{2}$ is determined in the output layer through Equation (12):

$$
a^{2}=w^{2} a^{1}+b^{2}
$$

Finally, the MSE performance index is determined using Equation (13) for the training set [23]:

$$
F(x)=\sum_{q=1}^{Q}\left(t_{q}-a_{q}^{2}\right)^{T}\left(t_{q}-a_{q}^{2}\right)
$$

The newrb function of MATLAB was used for modeling the sedimentation rate and turbidity using the RBFN. Two RBFNs were built, one for the sedimentation rate and another for the turbidity. Both networks have three input variables $\left(\mathrm{Ca}^{2+}\right.$ and $\mathrm{Mg}^{2+}$ concentrations and $\left.\mathrm{pH}\right)$. The newrb function works with the following code: net $=$ newrb $(p, t, \mathrm{GOAL}$, SPREAD). The $p$ matrix represents the input variables and $t$ the output variables. GOAL is the target error and SPREAD represents the spread width, which can take different values that will influence the MSE. The network is developed by adding one neuron at a time, and each calculates the MSE. In the iterative process, the MSE value is compared with the GOAL, and if the MSM is equal to or less than GOAL, then, the process converges; otherwise, another neuron is added and so on [24]. This iterative process is performed for various values of SPREAD.

It is worth indicating that the RBFN was selected because a recent study shows that the RBFN performs better than multi-layer perceptron networks when it is applied to response surface methodology [25]. Another advantage of the RBFN over other neural networks is that during RBFN learning, the inputs are fed directly from the hidden layer without any weight, and the weights are only manifested between the hidden and the output layer. Such weights are modified depending on the error. Thus, the RBFN requires a much shorter learning time compared to multi-layer feedback neural networks used in other practical applications, and therefore, the convergence time is also considerably short [26].

\section{Results and Discussions}

\subsection{Sedimentation Tests in Artificial Seawater}

Table 4 summarizes the results in terms of $\mathrm{Sr}, \mathrm{Cp}, \% \mathrm{WR}$, and $\mathrm{T}$ of the 27 experimental sedimentation tests in artificial seawater (ASw). The results were obtained combining factorially the three selected 
parameters (i.e., $\mathrm{Ca}^{2+}, \mathrm{Mg}^{2+}$, and $\mathrm{pH}$ ), as indicated in the first three columns of Table 4 . The ionic strength of ASw (I) is also incorporated. Note that when the concentration is $0 \mathrm{mg} \cdot \mathrm{L}^{-1}$ for both $\mathrm{Ca}^{2+}$ and $\mathrm{Mg}^{2+}$ ions, the ionic strength is $0.52 \mathrm{~mol} \cdot \mathrm{L}^{-1}$. This condition is due to the composition of ASw, which has other salts described in Table 2.

Table 4. Results of sedimentation tests in ASw.

\begin{tabular}{|c|c|c|c|c|c|c|c|}
\hline \multicolumn{4}{|c|}{ Independent Parameters } & \multicolumn{4}{|c|}{ Response Parameters } \\
\hline $\mathrm{Ca}^{2+}\left(\mathrm{mg} \cdot \mathrm{L}^{-1}\right)$ & $\mathrm{Mg}^{2+}\left(\mathrm{mg} \cdot \mathrm{L}^{-1}\right)$ & $\mathrm{pH}$ & I $\left(\mathrm{mol}^{\prime} \mathrm{L}^{-1}\right)$ & $\mathrm{Sr}\left(\mathrm{m} \cdot \mathrm{h}^{-1}\right)$ & $C p(w / w)$ & $\%$ WR (\%) & T (FNU) \\
\hline 418.89 & 1327 & 9.3 & 0.71 & 7.368 & 0.475 & 87.4 & 77.8 \\
\hline 418.89 & 1327 & 10.5 & 0.71 & 6.006 & 0.427 & 84.7 & 47.2 \\
\hline 418.89 & 1327 & 11.5 & 0.71 & 0.403 & 0.255 & 66.6 & 38.6 \\
\hline 418.89 & 663.5 & 9.3 & 0.63 & 3.266 & 0.454 & 86.3 & 88 \\
\hline 418.89 & 663.5 & 10.5 & 0.63 & 4.495 & 0.448 & 86.0 & 98.9 \\
\hline 418.89 & 663.5 & 11.5 & 0.63 & 4.293 & 0.400 & 82.9 & 48.7 \\
\hline 418.89 & 0 & 9.3 & 0.55 & 4.535 & 0.481 & 87.7 & 106 \\
\hline 418.89 & 0 & 10.5 & 0.55 & 4.289 & 0.481 & 87.7 & 102 \\
\hline 418.89 & 0 & 11.5 & 0.55 & 7.352 & 0.462 & 86.7 & 117 \\
\hline 209.4 & 1327 & 9.3 & 0.70 & 4.703 & 0.476 & 87.5 & 132 \\
\hline 209.4 & 1327 & 10.5 & 0.70 & 6.451 & 0.438 & 85.4 & 95 \\
\hline 209.4 & 1327 & 11.5 & 0.70 & 0.579 & 0.271 & 69.4 & 13.8 \\
\hline 209.4 & 663.5 & 9.3 & 0.62 & 3.505 & 0.462 & 86.7 & 84.5 \\
\hline 209.4 & 663.5 & 10.5 & 0.62 & 4.059 & 0.419 & 84.2 & 26.2 \\
\hline 209.4 & 663.5 & 11.5 & 0.62 & 2.137 & 0.391 & 82.3 & 15.2 \\
\hline 209.4 & 0 & 9.3 & 0.54 & 7.804 & 0.477 & 87.5 & 120 \\
\hline 209.4 & 0 & 10.5 & 0.54 & 7.515 & 0.455 & 86.4 & 151 \\
\hline 209.4 & 0 & 11.5 & 0.54 & 6.047 & 0.475 & 87.4 & 128 \\
\hline 0 & 1327 & 9.3 & 0.68 & 4.206 & 0.485 & 87.9 & 13.8 \\
\hline 0 & 1327 & 10.5 & 0.68 & 4.249 & 0.451 & 86.2 & 137 \\
\hline 0 & 1327 & 11.5 & 0.68 & 0.639 & 0.279 & 70.6 & 9.72 \\
\hline 0 & 663.5 & 9.3 & 0.60 & 3.367 & 0.467 & 87.0 & 66.7 \\
\hline 0 & 663.5 & 10.5 & 0.60 & 6.887 & 0.416 & 84.1 & 39.3 \\
\hline 0 & 663.5 & 11.5 & 0.60 & 2.108 & 0.381 & 81.6 & 14.5 \\
\hline 0 & 0 & 9.3 & 0.52 & 3.418 & 0.488 & 88.1 & 238 \\
\hline 0 & 0 & 10.5 & 0.52 & 3.444 & 0.486 & 88.0 & 218 \\
\hline 0 & 0 & 11.5 & 0.52 & 2.965 & 0.467 & 87.0 & 85 \\
\hline
\end{tabular}

Figure 4 shows the decrease in $\mathrm{Sr}$ and $\mathrm{T}$ for high $\mathrm{Mg}^{2+}$ concentrations $\left(1327 \mathrm{mg} \cdot \mathrm{L}^{-1}\right)$ at $\mathrm{pH}$ 10.5-11.5, which demonstrates the effect of $\mathrm{pH}$ and $\mathrm{Mg}^{2+}$ in $\mathrm{Sr}$ and $\mathrm{T}$. Furthermore, it is noted that at $\mathrm{pH} 10.5$, the sedimentation rates are the highest and at $\mathrm{pH} 11.5$, the turbidity values are the lowest.

With this explanation, it is observed that the graphs in Figure 4 do not show an ordered and proportional sequence, and this result can be due to the non-monotonous behavior of such ions in the progress of the process [27]. Therefore, the model capable of fitting the data is complex. An adjustment was made with the Multiple Regression method by using Minitab software version 19.1 (State College, PA, USA) and two equations governing the behavior of the settling rate (Sr) and turbidity (T) were obtained. However, the adjusted $\mathrm{R}^{2}$ of those equations resulted in being $14 \%$ and $35 \%$, respectively. Several multiphase systems do not follow a second-order polynomial behavior like what was observed here. The immediate consequence is incorrect optimization. In these cases, the most popular alternative is to use ANNs [28]. For this reason, the RBFN method was chosen, and it was advantageous to show more comprehensively the results (see Section 3.2).

To better understand the results of $\mathrm{Sr}$ and $\mathrm{T}$ obtained from the sedimentation tests, in Figure 5, such response parameters are studied in the function of the solution ionic strength (I). It is well known that I depends on the dissociation degrees of salts in water and the concentration of ions and their valence [29]; therefore, the nine combinations of $\mathrm{Ca}^{2+}$ and $\mathrm{Mg}^{2+}$ concentrations resulted in nine different values of I, as indicated in the X-axis of the graphs in Figure 5.

According to Mpofu et al. [30], an increase in ionic strength can reduce the repulsive force barrier between particles by compressing the thickness of the double layer, thus, enabling particle aggregation and consequently, improving sedimentation process performance. As all ions dissolved in the water contribute to the value of ionic strength and not only those divalent investigated in this study, it is 
crucial to know the complete chemical composition of water. The experimental results show that at $\mathrm{pH}$ 9.3, 10.5, and 11.5, high settling rate and a low residual turbidity are achievable with the following conditions: (i) at $\mathrm{pH}=9.3$ with $\mathrm{I}=0.68 \mathrm{~mol} \cdot \mathrm{L}^{-1}$; (ii) at $\mathrm{pH}=10.5$ with $\mathrm{I}=0.60 \mathrm{~mol} \cdot \mathrm{L}^{-1}$; (iii) at $\mathrm{pH}=11.5$ with $\mathrm{I}=0.60 \mathrm{~mol} \cdot \mathrm{L}^{-1}$.
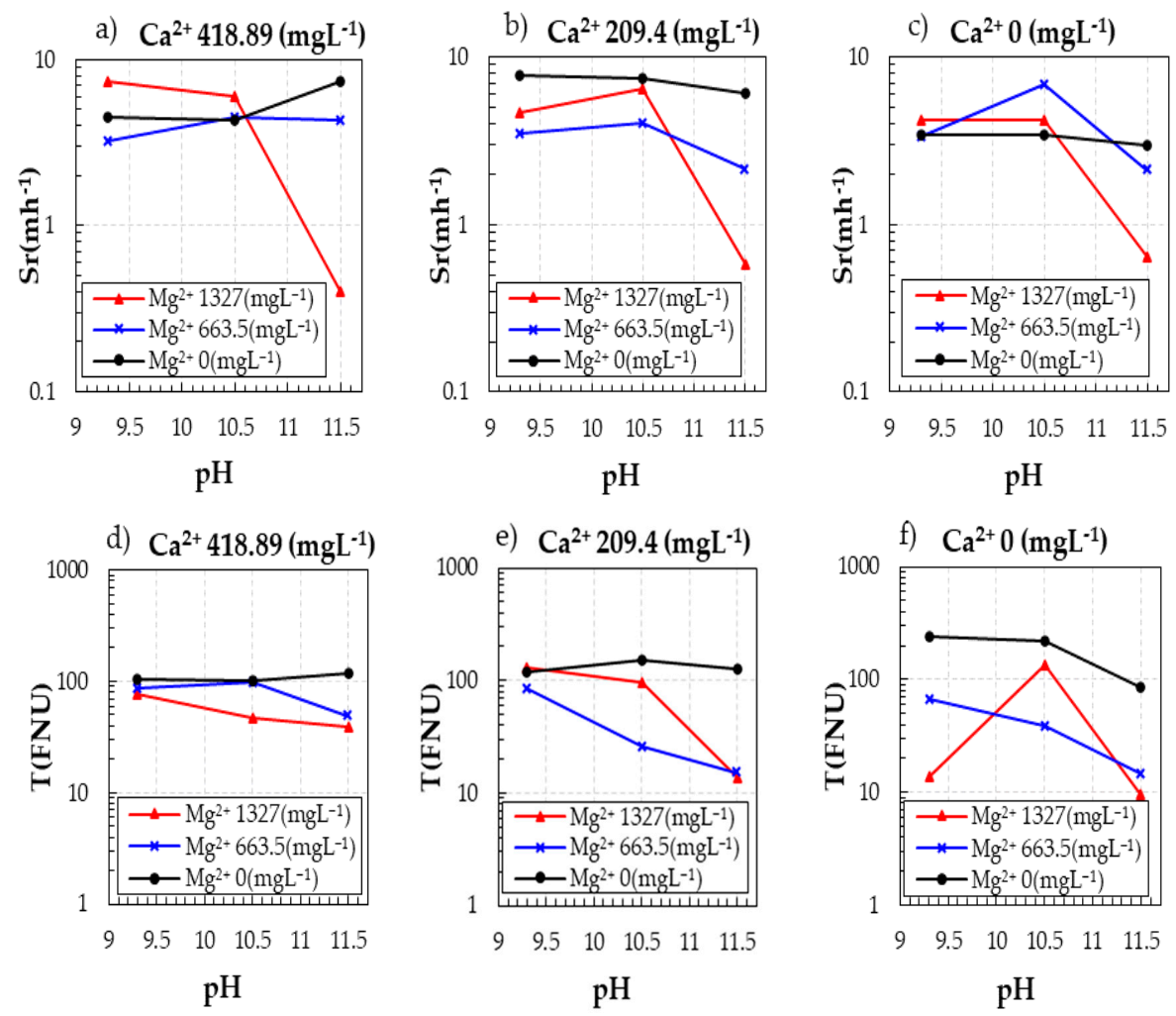

Figure 4. Trends of settling rate (Sr) and turbidity (T) by varying $\mathrm{Ca}^{2+}$ and $\mathrm{Mg}^{2+}$ concentrations as well as pH. (a) Sr at $418 \mathrm{mg} \cdot \mathrm{L}^{-1}$ of $\mathrm{Ca}^{2+}$, (b) Sr at $209.4 \mathrm{mg} \cdot \mathrm{L}^{-1}$ of $\mathrm{Ca}^{2+}$, (c) Sr at $0 \mathrm{mg} \cdot \mathrm{L}^{-1}$ of $\mathrm{Ca}^{2+}$, (d) T at $418 \mathrm{mg} \cdot \mathrm{L}^{-1}$ of $\mathrm{Ca}^{2+}$, (e) $\mathrm{T}$ at $209.4 \mathrm{mg} \cdot \mathrm{L}^{-1}$ of $\mathrm{Ca}^{2+}$, (f) $\mathrm{T}$ at $0 \mathrm{mg} \cdot \mathrm{L}^{-1}$ of $\mathrm{Ca}^{2+}$.
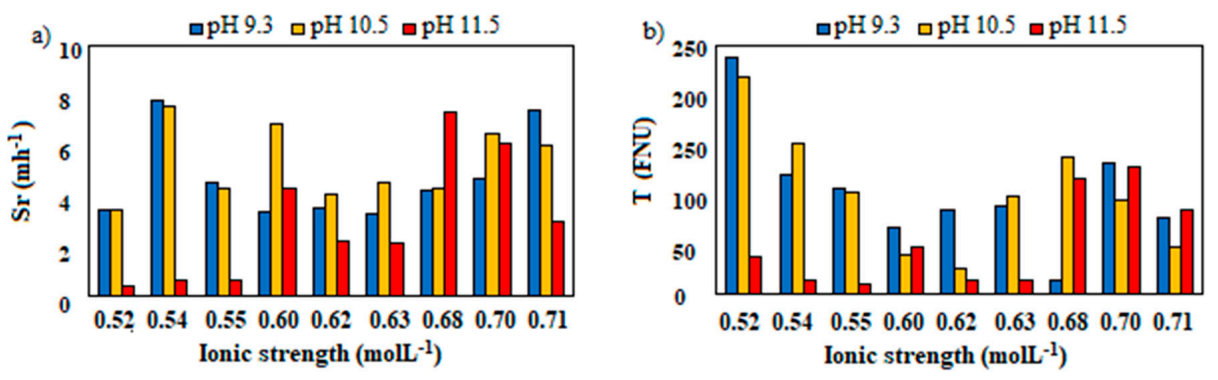

Figure 5. Mine tailings settling rate and turbidity as a function of the ionic strength at $\mathrm{pH} 9.3,10.5$, and 11.5. (a) Mine tailings settling rate and (b) turbidity as a function of Ionic strength at different $\mathrm{pH}$ values.

Figure 6 shows the trends of $\% \mathrm{WR}, \mathrm{Cp}$, and $\mathrm{NaOH}$, varying the concentrations of $\mathrm{Ca}^{2+}$ and $\mathrm{Mg}^{2+}$ and the $\mathrm{pH}$ according to the selected ranges. It can be seen that the $\mathrm{Ca}^{2+}$ concentration minimally affects the performance of the sedimentation process of the three selected response parameters. A different conclusion is reached when the effect of $\mathrm{Mg}^{2+}$ concentration is taken into account: when the $\mathrm{Mg}^{2+}$ concentration increases, \% WR, and $\mathrm{Cp}$ decrease, while $\mathrm{NaOH}$ consumption increases. For example, at the highest concentration of $\mathrm{Mg}^{2+}$ (i.e., $1327 \mathrm{mg} \cdot \mathrm{L}^{-1}$ ), \% WR decreases approximately by $20 \%$, Cp decreases from 0.5 to 0.3 , and $\mathrm{NaOH}$ consumption is $5-8$ times higher in the $\mathrm{pH}$ range 10.5-11.5, than in the range 9.3-10.5. This result is due to the strong buffer effect of seawater in a zone that 
coincides with the formation of solid magnesium species [31,32]. These results agree with those reported by Ramos et al. [15], who stated that the presence of magnesium precipitates deactivated the functional groups of anionic polyacrylamides. The flocculant lost selectivity, thus, being unable to bridge particles that led to large aggregates. However, in the $\mathrm{pH}$ range considered in this study, calcium is mainly dissolved in solution, so its impact on flocculant performance is not as relevant as magnesium.

a) $\mathrm{Ca}^{2+} 418.89 \mathrm{mg} \cdot \mathrm{L}^{-1}$

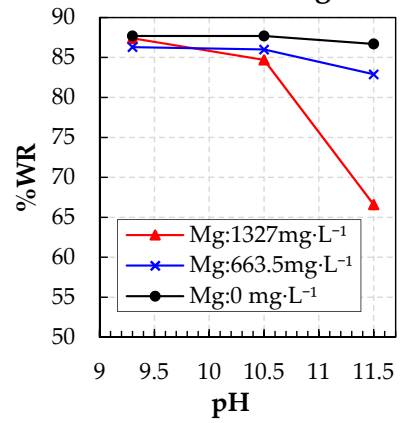

d) $\mathrm{Ca}^{2+} 418.89 \mathrm{mg} \cdot \mathrm{L}^{-1}$

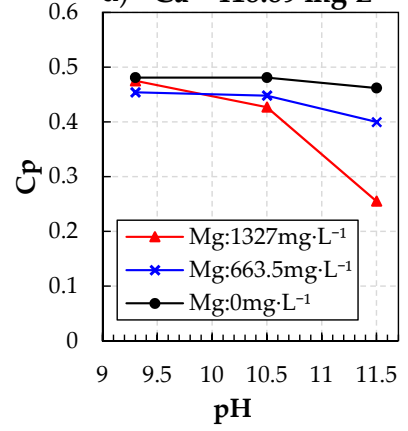

g) $\mathrm{Ca}^{2+} 418.89 \mathrm{mg} \cdot \mathrm{L}^{-1}$

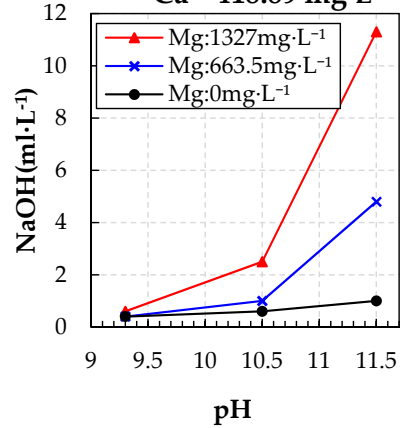

b) $\mathrm{Ca}^{2+} 209.4 \mathrm{mg} \cdot \mathrm{L}^{-1}$

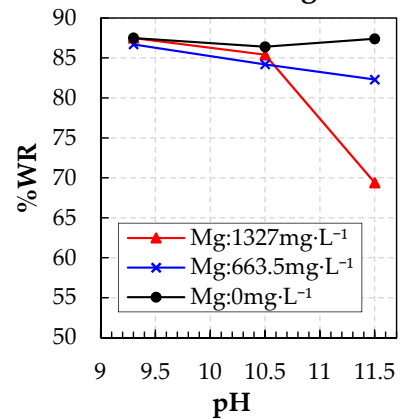

e) $\mathrm{Ca}^{2+} \mathbf{2 0 9 . 4} \mathbf{m g} \cdot \mathrm{L}^{-1}$

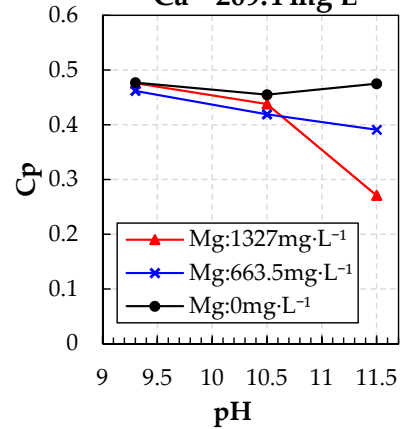

h) $\mathrm{Ca}^{2+} \mathbf{2 0 9 . 4} \mathrm{mg} \cdot \mathrm{L}^{-1}$

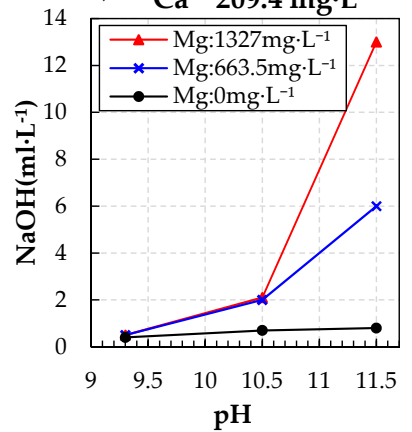

c) $\mathrm{Ca}^{2+} \mathbf{0 ~ m g} \cdot \mathrm{L}^{-1}$

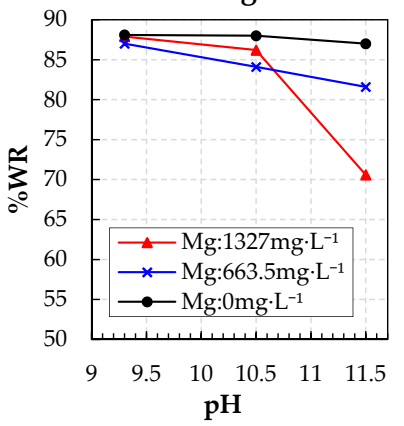

f) $\mathrm{Ca}^{2+} \mathbf{0} \mathbf{m g} \cdot \mathrm{L}^{-1}$

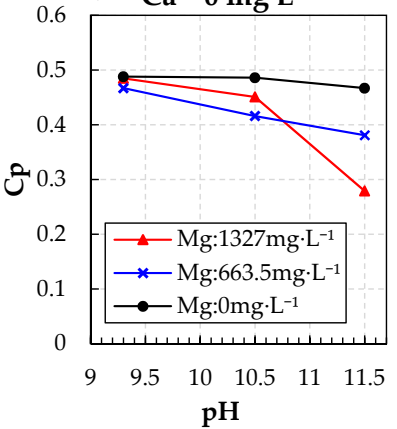

i) $\mathrm{Ca}^{2+} 0 \mathrm{mg} \cdot \mathrm{L}^{-1}$

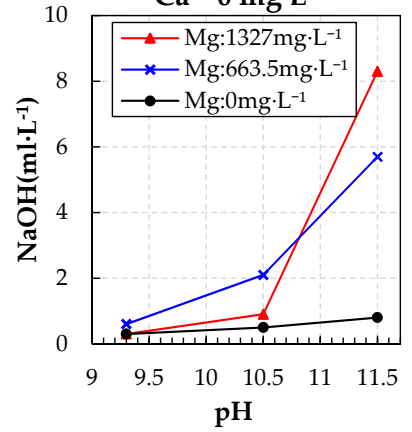

Figure 6. Trends of solid fraction (Cp), water recovery (\% WR), and $\mathrm{NaOH}$ solution consumption by varying $\mathrm{Ca}^{2+}$ and $\mathrm{Mg}^{2+}$ concentrations as well as $\mathrm{pH}$. (a) \% WR at $418.89 \mathrm{mg} \cdot \mathrm{L}^{-1}$ of $\mathrm{Ca}^{2+}$, (b) \%WR at $209.4 \mathrm{mg} \cdot \mathrm{L}^{-1}$ of $\mathrm{Ca}^{2+}$, (c) \%WR at $0 \mathrm{mg} \cdot \mathrm{L}^{-1}$ of $\mathrm{Ca}^{2+}$, (d) $\mathrm{Cp}$ at $418.89 \mathrm{mg} \cdot \mathrm{L}^{-1}$ of $\mathrm{Ca}^{2+}$, (e) Cp at $209.4 \mathrm{mg} \cdot \mathrm{L}^{-1}$ of $\mathrm{Ca}^{2+}$, (f) $\mathrm{Cp}$ at $0 \mathrm{mg} \cdot \mathrm{L}^{-1}$ of $\mathrm{Ca}^{2+}$, (g) $\mathrm{NaOH}$ solution consumption at $418.89 \mathrm{mg} \cdot \mathrm{L}^{-1}$ of $\mathrm{Ca}^{2+}$, (h) $\mathrm{NaOH}$ solution consumption at $209.4 \mathrm{mg} \cdot \mathrm{L}^{-1}$ of $\mathrm{Ca}^{2+}$, (i) $\mathrm{NaOH}$ solution consumption at $0 \mathrm{mg} \cdot \mathrm{L}^{-1}$ of $\mathrm{Ca}^{2+}$.

\subsection{Analysis of the Radial Basis Function Network (RBFN) Model}

Artificial neural networks allow experimental data to be processed, generating a predictive dataset (RBFN output data) which is suitable for achieving the optimal solution of non-linear equations [33]. After calibration, the RBFN model turns to be a potent tool capable of predicting, with accuracy, the output response variables from any combination of input values (independent variables). Recall that the RBFN structure has an input layer, a hidden layer, and an output layer. Within our case, the RBFN 
has three input variables $\left(\mathrm{Ca}^{2+}\right.$ concentration, $\mathrm{Mg}^{2+}$ concentration, and $\mathrm{pH}$ ) and two output variables (Sedimentation Rate, Sr, and Turbidity, T). The MATLAB computer program was used to find the optimal number of neurons and the width (w) described in Section 2.7. The objective function was to minimize MSE [34].

In data processing with RBFN, 27 data points were processed for settling rate and turbidity. In the first step, the three input variables were normalized to values in the range [0,1] to facilitate the calculation and eliminate the influence of dimension. In the second step, the function newrb $(p, t, G O A L$, SPREAD) of MATLAB was applied with a GOAL of 0.05. Several values of SPREAD were employed and SPREAD values of 2.49 and 0.4 were found for the settling rate and turbidity, respectively. For these SPREAD values, 20 and 25 neurons were obtained for settling rate and turbidity networks. Figure 7 provides the RBFN structures obtained. Table 5 presents weight $\mathbf{w}$ and bias $\mathbf{b}$ values for hidden $\left(w^{1}, b^{1}\right)$ and output layer $\left(w^{2}, b^{2}\right)$ for settling rate and turbidity, respectively.

a)

Hidden layer

Output Layer
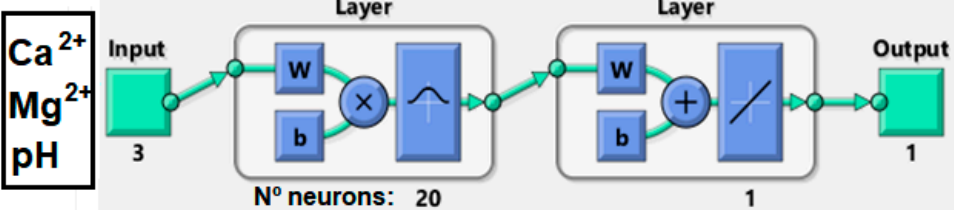

Settling

rate $\mathrm{Sr}$

b)

Hidden layer

Output Layer

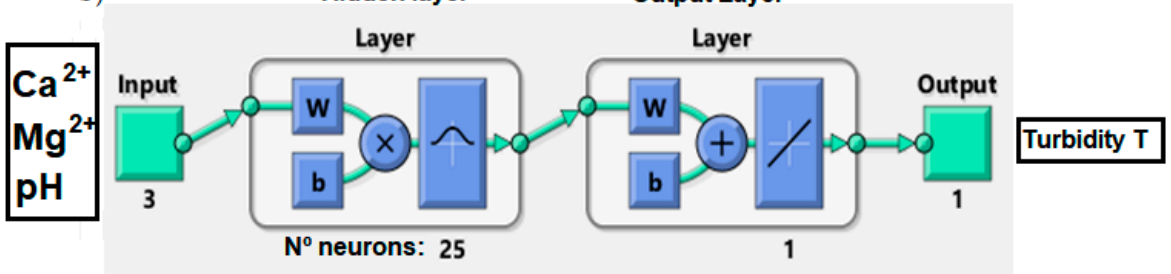

Figure 7. MATLAB structure for the RBFN (a) settling rate and (b) turbidity.

Table 5. Settling rate and turbidity weights $(\mathrm{w})$ and bias $(\mathrm{b})$ values from processing data by MATLAB.

\begin{tabular}{|c|c|c|c|c|c|c|c|c|c|c|c|}
\hline \multicolumn{6}{|c|}{ Settling Rate Sr } & \multicolumn{6}{|c|}{ Turbidity $\mathrm{T}$} \\
\hline & $w^{1}$ & & $w^{2 \mathrm{~T}}$ & $b^{1}$ & $b^{2}$ & & $w^{1}$ & & $w^{2 \mathrm{~T}}$ & $b^{1}$ & $b^{2}$ \\
\hline 1 & 0 & 0 & $160,320.7$ & 0.3344 & -53.425 & 0 & 0 & 0.5455 & 174.2 & 2.0814 & -2.622 \\
\hline 0.4999 & 1 & 1 & $583,055.1$ & & & 1 & 0 & 0.5455 & -10.8 & & \\
\hline 1 & 0.5 & 0.5455 & $400,102.9$ & & & 0 & 0 & 0 & 198.1 & & \\
\hline 1 & 1 & 1 & $-227,975.1$ & & & 0.4999 & 1 & 0 & 123.2 & & \\
\hline 0 & 0.5 & 1 & $386,413.9$ & & & 0 & 1 & 0.5455 & 196.2 & & \\
\hline 0 & 0 & 1 & $-126,579.5$ & & & 0.4999 & 0 & 1 & 71.7 & & \\
\hline 0 & 1 & 1 & $-245,670.7$ & & & 1 & 0.5 & 0 & 8.9 & & \\
\hline 0.4999 & 0 & 0.5455 & $232,292.3$ & & & 0 & 0.5 & 0.5455 & -88.9 & & \\
\hline 1 & 0.5 & 1 & $252,277.5$ & & & 0 & 1 & 0 & -76.5 & & \\
\hline 0.4999 & 0 & 1 & $256,532.2$ & & & 0 & 1 & 1 & -67.4 & & \\
\hline 0 & 1 & 0 & $17,756.8$ & & & 1 & 1 & 1 & 43.5 & & \\
\hline 0.4999 & 1 & 0.5455 & $-141,222.4$ & & & 1 & 0 & 0 & 92.4 & & \\
\hline 1 & 0 & 0.5455 & $-380,104.8$ & & & 1 & 0 & 1 & 90.2 & & \\
\hline 0 & 0 & 0.5455 & $-107,365.3$ & & & 1 & 0.5 & 0.5455 & 99.9 & & \\
\hline 1 & 0.5 & 0 & $-223,612.6$ & & & 0.4999 & 0.5 & 1 & -14.4 & & \\
\hline 1 & 1 & 0.5455 & $-83,433.9$ & & & 0.4999 & 0.5 & 0.5455 & -75.0 & & \\
\hline 0 & 0.5 & 0.5455 & $64,578.8$ & & & 0.4999 & 0 & 0.5455 & 56.4 & & \\
\hline 0.4999 & 0.5 & 1 & $-870,233.9$ & & & 1 & 0.5 & 1 & -28.2 & & \\
\hline 0.4999 & 0 & 0 & $-39,731.5$ & & & 0.4999 & 1 & 0.5455 & 33.6 & & \\
\hline \multirow[t]{6}{*}{1} & 1 & 0 & $92,488.7$ & & & 0 & 0.5 & 1 & 30.6 & & \\
\hline & & & & & & 1 & 1 & 0 & 28.5 & & \\
\hline & & & & & & 1 & 1 & 0.5455 & -23.2 & & \\
\hline & & & & & & 0 & 0 & 1 & -12.6 & & \\
\hline & & & & & & 0.4999 & 0.5 & 0 & 19.1 & & \\
\hline & & & & & & 0.4999 & 0 & 0 & -10.6 & & \\
\hline
\end{tabular}


According to values shown in Table 6, the statistical parameter $\mathrm{R}^{2}$ resulting from the calibration process was 0.98 and 0.99 for $\mathrm{Sr}$ and $\mathrm{T}$, respectively. These values, coupled with other statistical parameters reported in Table 6, corroborate the reliability of the RBFN model in simulating results from the sedimentation process. Figure 8 shows graphically the fitting between experimental data and those predicted by the RBFN model.

Table 6. Statistical parameters resulting from the calibration of the Radial Basis Function Network (RBFN) model.

\begin{tabular}{ccc}
\hline \multirow{2}{*}{ Statistical Parameters } & \multicolumn{2}{c}{ Value } \\
\cline { 2 - 3 } & Sr Prediction & T Prediction \\
\hline Mean relative error & 0.1104 & 0.00597 \\
Mean square error & 0.1638 & 0.29917 \\
Root mean square & 0.4047 & 0.54697 \\
R squared & 0.9809 & 0.99996 \\
Adjusted R squared & 0.9774 & 0.99995 \\
\hline
\end{tabular}
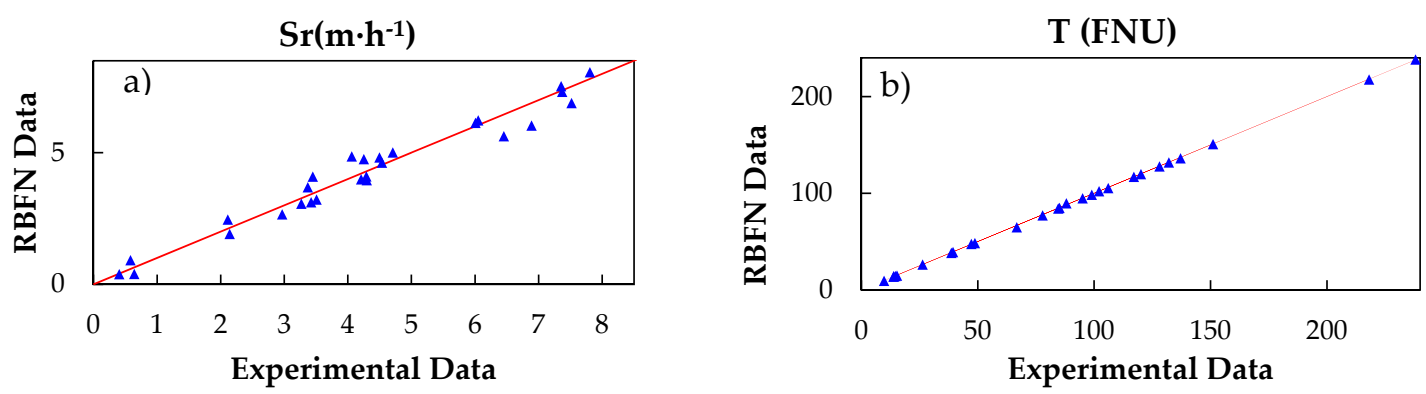

Figure 8. Comparison between experimental data and predicted data by the Radial Basis Function Network (RBFN) model for (a) Settling rate (Sr), (b) Turbidity (T).

\subsection{Radial Basis Function Network (RBFN) Validation}

There are different methods of network validation. These methods mainly depend on the amount of data available. According to Kopal et al. [35], three ways of validation are known. For a small dataset, the following validation method is adequate. The idea of this method is to train the network several times using the following methodology: from a set composed of a number $n$ of samples or points, one of them is omitted, and the neural network is trained; then, the next point is omitted, and the neural network is re-trained; therefore, one point at a time is removed and the network is trained. This process is iteratively performed as long as $n$ subsets of response data are generated. One of them is left for validation; therefore, $n-1$ sets of responses are used to calibrate the model, and the remaining one is used for its validation.

The validation results are displayed in Figure 9, where the calculated values (average data) are compared with the last 27th set of data (validation). According to the previously described procedure, the validation for the Settling rate (Sr) and Turbidity (T) have adjusted $\mathrm{R}^{2}$ of 0.90 and 0.92 , respectively.
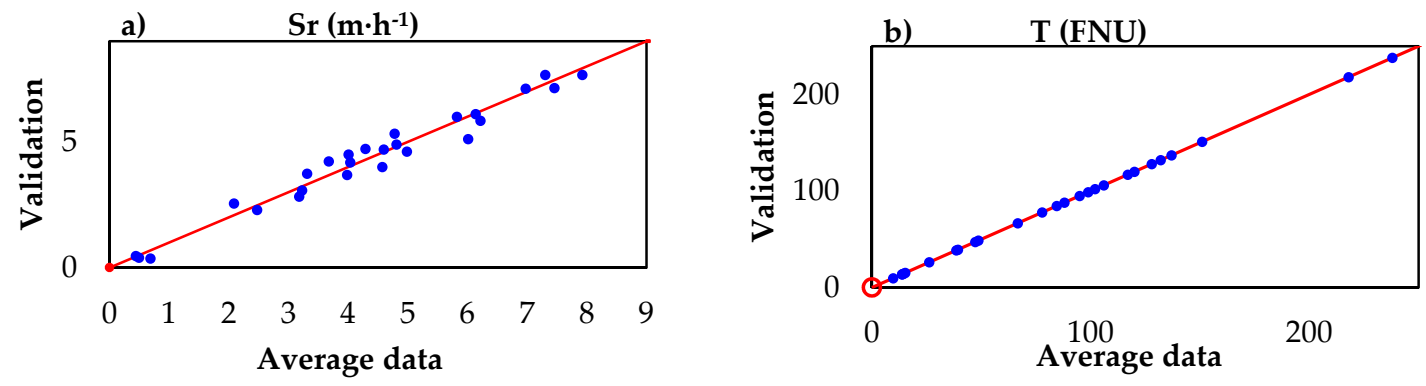

Figure 9. Comparison between validation and average data in the validation process for (a) Settling rate (Sr), (b) Turbidity (T). 


\subsection{Calcium and Magnesium Influence in Settling Rate (Sr) and Turbidity (T)}

From the 3D surfaces plotted for different $\mathrm{pH}$ values (i.e., 9.3, 10.5, and 11.5) in Figure 10, it can be visibly noticed the variations of Sr (Figure 10a,c,e) and T (Figure 10b,d,f), predicted by the RBNF model as functions of $\mathrm{Ca}^{2+}$ and $\mathrm{Mg}^{2+}$ concentrations. The optimal range of the three independent variables can be found by setting as targets the maximization of tailings settling rate and the minimization of the supernatant turbidity.
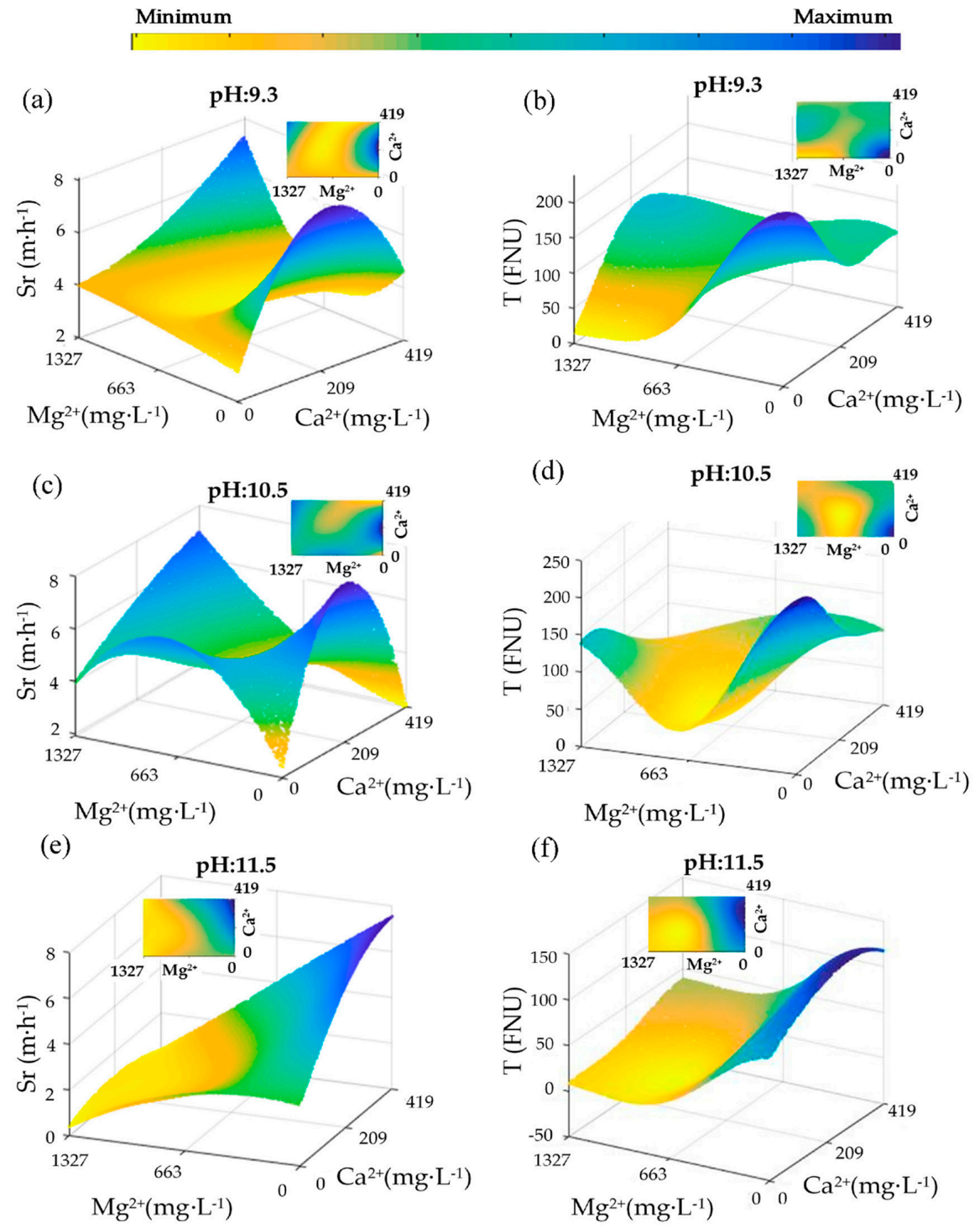

Figure 10. Response surface method (RSM) analysis from data elaborated by the Radial Basis Function Network (RBFN) model for $\mathrm{Sr}$ and $\mathrm{T}$ as functions of $\mathrm{Ca}^{2+}$ and $\mathrm{Mg}^{2+}$ concentrations at different $\mathrm{pH}$ : $(\mathbf{a}, \mathbf{b})$ for $\mathrm{pH} 9.3$; (c,d) for $\mathrm{pH} 10.5$; (e,f) for $\mathrm{pH} 11.5$.

Figure 10a shows two Sr maximum points at $\mathrm{pH}$ 9.3: the highest corresponds to concentrations of $\mathrm{Ca}^{2+}=205-254$ and $\mathrm{Mg}^{2+}=1-27 \mathrm{mg} \cdot \mathrm{L}^{-1}$, whereas the second shows $\mathrm{Ca}^{2+}=401-418$ and $\mathrm{Mg}^{2+}=1295-1326 \mathrm{mg} \cdot \mathrm{L}^{-1}$. At this $\mathrm{pH}$, most of the ions are dissolved, and some chemical complexes like $\mathrm{Ca}(\mathrm{OH})^{+}$and $\mathrm{Mg}(\mathrm{OH})^{+}$can be formed. According to the literature, these species would limit the volume of the polyacrylamide in the solutions. However, the play between polymer adsorption and its size in solution means that the sedimentation responses are not monotonous concerning the concentration of each ion. Turbidity is reported in Figure $10 \mathrm{~b}, \mathrm{~d}$, and only a point of minimum is present for concentrations of $\mathrm{Ca}^{2+}=0-30 \mathrm{mg} \cdot \mathrm{L}^{-1}$ and $\mathrm{Mg}^{2+}=1167-1324 \mathrm{mg} \cdot \mathrm{L}^{-1}$. 
At $\mathrm{pH}=10.5$ in Figure 10c, it can be noticed three points of the maximum value for Sr; two of them coincide with the two peaks indicated for $\mathrm{pH}=9.3$, whereas the third point is placed in correspondence of concentrations of $\mathrm{Ca}^{2+}=1-12 \mathrm{mg} \cdot \mathrm{L}^{-1}$ and $\mathrm{Mg}^{2+}=608-875 \mathrm{mg} \cdot \mathrm{L}^{-1}$. At $\mathrm{pH}=10.5$, the mine tailings settling rates are, on average, higher than those at $\mathrm{pH}=9.3$. This aspect is due to the different speciation of $\mathrm{Ca}^{2+}$ and $\mathrm{Mg}^{2+}$ ions induced by different values of $\mathrm{pH}$. At $\mathrm{pH}=9.3, \mathrm{Ca}^{2+}$ and $\mathrm{Mg}^{2+}$ ions mainly are dissolved in an ionized state or form positively charged complexes (i.e., $\mathrm{Ca}(\mathrm{OH})^{+}$and $\mathrm{Mg}(\mathrm{OH})^{+}$). In both cases, the presence of positive charges on their surface drives them to be adsorbed by the negatively charged polymer flocculant in competition with colloidal solids or also be adsorbed by colloidal solids and stabilize them. For this condition of $\mathrm{pH}$ (i.e., 10.5), the area of minimum turbidity is for concentrations of $\mathrm{Ca}^{2+}$ lower than $251 \mathrm{mg} \cdot \mathrm{L}^{-1}$ and $\mathrm{Mg}^{2+}$ between 400 and $800 \mathrm{mg} \cdot \mathrm{L}^{-1}$ (Figure 10d).

Figure $10 \mathrm{e}$ for $\mathrm{pH}=11.5$ shows a unique maximum peak of $\mathrm{Sr}$ at the highest $\mathrm{Ca}^{2+}$ and lowest $\mathrm{Mg}^{2+}$ concentration simultaneously. In these conditions of $\mathrm{pH}$, mine tailings settling rate and supernatant turbidity are, on average, both lower than those evaluated at $\mathrm{pH}=9.3$ and $\mathrm{pH}=10.5$. Increased $\mathrm{Mg}^{2+}$ removal leads to a higher sedimentation rate, while $\mathrm{Ca}^{2+}$ plays a beneficial role within the concentration range. With this, it is suggested that the effort in the treatment of seawater be focused on removing $\mathrm{Mg}^{2+}$ ions to reduce the presence of solid precipitates, but $\mathrm{Ca}^{2+}$ does not show harmful effects. However, it is necessary to be careful with the selected treatment, since Jeldres et al. [16] used lime to form the precipitates, which were subsequently removed by vacuum filtration. Although the authors focused on reducing the magnesium content, the remaining calcium concentration was over 2000 ppm. Until now, it is unknown if such a concentration level impacts on the efficiency of the process. In general, the turbidity of the supernatant (Figure 10f) is lower than that obtained at pH 9.3 (Figure 10b) and 10.5 (Figure 10d), especially the region with the highest magnesium concentration. The lower sedimentation rate leads to better quality clarification.

Table 7 summarizes the range of maximum values of $\mathrm{Sr}$ and the relative areas of $\mathrm{Ca}^{2+}$ and $\mathrm{Mg}^{2+}$ concentrations at different $\mathrm{pH}$. In contrast, Table 8 summarizes the range of minimum values of $\mathrm{T}$ and the relative areas of $\mathrm{Ca}^{2+}$ and $\mathrm{Mg}^{2+}$ concentrations at different $\mathrm{pH}$. The values of both tables result from the analysis of 3D surfaces in Figure 10.

Table 7. Optimal concentration ranges of $\mathrm{Ca}^{2+}$ and $\mathrm{Mg}^{2}$ for the highest mine tailings settling rate (Sr) as a function of $\mathrm{pH}$.

\begin{tabular}{cccc}
\hline $\mathbf{p H}$ & Settling Rate $\mathbf{( m \cdot \mathbf { h } ^ { - \mathbf { 1 } } )}$ & $\mathbf{C a}^{\mathbf{2 +}} \mathbf{( \mathbf { m g } \cdot \mathbf { L } ^ { - \mathbf { 1 } } )}$ & $\mathbf{M g}^{\mathbf{2 +}} \mathbf{( \mathbf { m g } \cdot \mathbf { L } ^ { - \mathbf { 1 } } )}$ \\
\hline \multirow{2}{*}{9.3} & $7.92-8.08$ & $205-254$ & $1-27$ \\
& $7.04-7.31$ & $401-418$ & $1295-1326$ \\
\hline \multirow{3}{*}{10.5} & $6.85-6.97$ & $182-224$ & $3-24$ \\
& $6.38-6.47$ & $386-418$ & $1286-1326$ \\
& $6.07-6.15$ & $1-12$ & $608-875$ \\
\hline 11.5 & $7.05-7.52$ & $387-418$ & $3-90$ \\
\hline
\end{tabular}

Table 8. Optimal concentration ranges of $\mathrm{Ca}^{2+}$ and $\mathrm{Mg}^{2}$ for the lowest residual turbidity (T) as a function of $\mathrm{pH}$.

\begin{tabular}{cccc}
\hline $\mathbf{p H}$ & Turbidity (FNU) & $\mathbf{C a}^{2+}\left(\mathbf{m g} \cdot \mathbf{L}^{-\mathbf{1}}\right)$ & $\mathbf{M g}^{\mathbf{2 +}} \mathbf{( \mathbf { m g } \cdot \mathbf { L } ^ { - \mathbf { 1 } } )}$ \\
\hline 9.3 & $15.55-34.30$ & $0-30$ & $1167-1324$ \\
\hline \multirow{2}{*}{10.5} & $25.19-38.72$ & $397-416$ & $1-72$ \\
& $34.56-39.12$ & $118-201$ & $597-796$ \\
\hline 11.5 & $0-10$ & $80-226$ & $796-1128$ \\
\hline
\end{tabular}

Table 9 shows, at different $\mathrm{pH}$, the optimal ranges of $\mathrm{Ca}^{2+}$ and $\mathrm{Mg}^{2+}$ concentration for optimizing, simultaneously, settling rate and turbidity. To find these optimums, an analysis of the 3D graphics was 
carried out by selecting areas that have high $\mathrm{Sr}$ and low $\mathrm{T}$. In this case, the peaks are areas that meet the requirements (Table 9 ).

Table 9. Concentration ranges of $\mathrm{Ca}^{2+}$ and $\mathrm{Mg}^{2}$ for optimizing the sedimentation process performance at $\mathrm{pH}$ of $9.3,10.5$, and 11.5 .

\begin{tabular}{|c|c|c|c|c|}
\hline $\mathrm{pH}$ & $\mathrm{Ca}^{2+}\left(\mathrm{mg} \cdot \mathrm{L}^{-1}\right)$ & $\mathrm{Mg}^{2+}\left(\mathrm{mg} \cdot \mathrm{L}^{-1}\right)$ & Settling Rate $\left(\mathrm{m} \cdot \mathrm{h}^{-1}\right)$ & Turbidity (FNU) \\
\hline 9.3 & $169-338$ & $0-130$ & $5.74-8.07$ & 103.8-143.6 \\
\hline 10.5 & $0-21$ & $400-741$ & $5.73-6.15$ & $44.54-63.07$ \\
\hline 11.5 & $377-418$ & $703-849$ & $2.6-3.7$ & $32.8-44.65$ \\
\hline
\end{tabular}

3.5. Sedimentation Tests in Chemically Pretreated Seawater (CHSw), Pretreated Seawater by Biomineralization (BSw), Tap Water (Tw) and Raw Seawater (Sw)

Figure 11 reports the response of five parameters (mine tailings settling rate, turbidity, $\mathrm{Cp}, \% \mathrm{WR}$, and $10 \mathrm{M} \mathrm{NaOH}$ solution volume consumption) for each aqueous medium investigated and three different $\mathrm{pH}(9.3,10.5$, and 11.5). For instance, in Figure 11a, the values of Sr resulting from four sedimentation tests are reported.
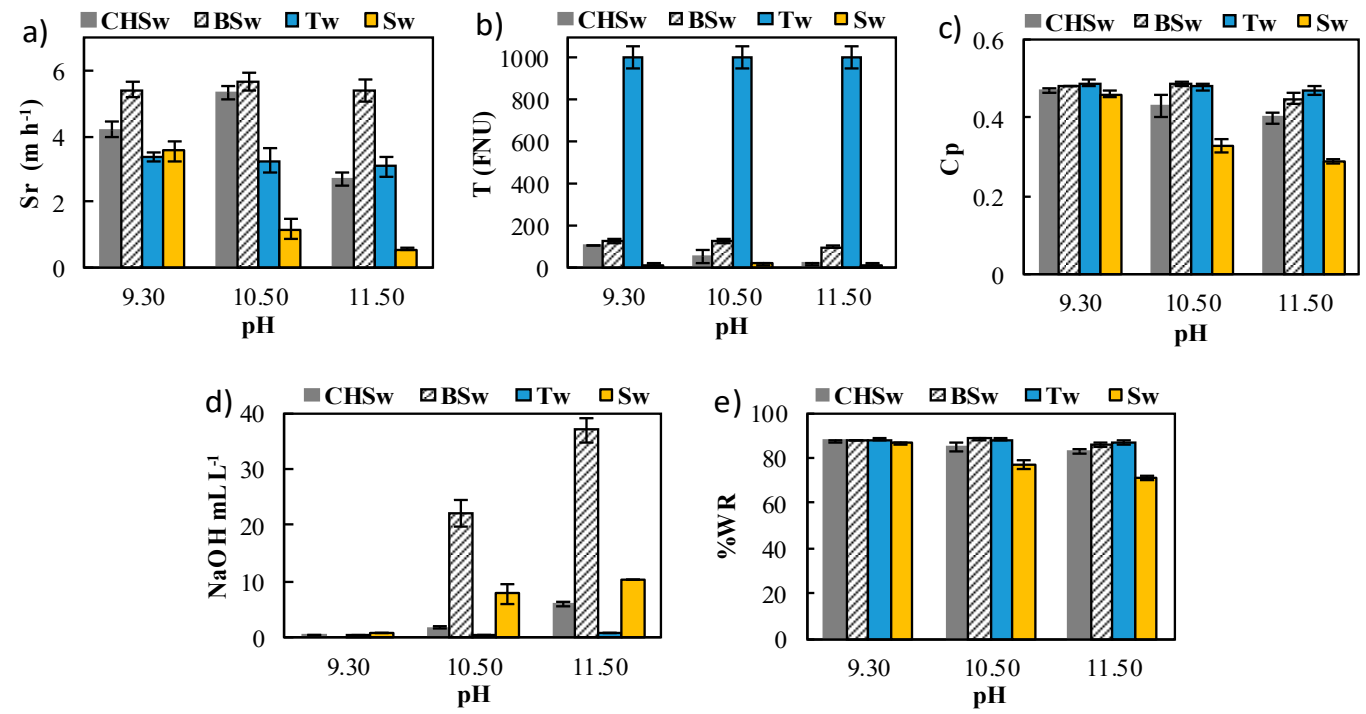

Figure 11. Process performance parameters (a) Settling rate (Sr), (b) Turbidity (T), (c) Solid fraction (Cp), (d) $\mathrm{NaOH}$ consumption, (e) Water recovery percentage (\%WR) in sedimentation tests and different aqueous media (i.e., Chemically pretreated seawater $(\mathrm{CHSw})$, Pretreated seawater by biomineralization (BSw), Tap water (Tw) and Raw Seawater (Sw) at different $\mathrm{pH}$ values (i.e., 9.3, 10.5, and 11.5).

In this figure, it can be noticed that the highest Sr values (i.e., 5.4, 5.7, and $5.4 \mathrm{~m} \cdot \mathrm{h}^{-1}$ ) were reached independently of $\mathrm{pH}$ when BSw was used as the separation medium. The ANOVA analysis indicates significant differences between means of one type of water compared with the others when the $\mathrm{Sr}$ is evaluated, thus, obtaining the best results in BSw. This result is reasonable due to the presence of a high concentration of $\mathrm{NH}_{4}{ }^{+}$ion ranging from 4000 and $7000 \mathrm{mg} \cdot \mathrm{L}^{-1}$ in the liquid bulk used to produce BSw. The $\mathrm{NH}_{4}{ }^{+}$concentration in the medium is due to urea hydrolysis by urease enzyme from $B$. subtilis LN8B. Per mole of urea, urease enzyme hydrolyzes urea into one mole of carbonate ion and two moles of ammonium ion. Carbonate ions precipitate as calcium carbonate in the presence of calcium ions from seawater, decreasing its concentration as a soluble ion [18]. On the other hand, $\mathrm{NH}_{4}{ }^{+}$ions can remain in solution or form precipitates as struvite or another crystal, helping to reduce the soluble concentration of $\mathrm{Mg}^{2+}$ from seawater [36]. Soluble ammonium reacting with $\mathrm{OH}^{-}$dissolved in water forms $\mathrm{NH}_{3}{ }^{+}$and, at the same, reduces the concentration of $\mathrm{OH}^{-}$that, otherwise, would react with $\mathrm{Ca}^{2+}$ and $\mathrm{Mg}^{2+}$ to form solid complexes that reduce the performance of polyacrylamides (see Section 3.2). 
Focusing the attention on BSw, it can be noticed that residual turbidity (Figure 11b), as well as Cp (Figure 11c) and \% WR (Figure 11e), are not significantly affected by $\mathrm{pH}$. A different conclusion is drawn when $10 \mathrm{M} \mathrm{NaOH}$ solution is considered: actually, this parameter shows a proportional dependence on $\mathrm{pH}$; this result is expected as $\mathrm{NaOH}$ is used to regulate the $\mathrm{pH}$. For $\mathrm{CHSw}$, the highest mine tailings settling rate is reached at $\mathrm{pH}$ 10.5; the turbidity decreases with an inverse proportion tendency with $\mathrm{pH}$, even if all results are remarkable, because the residual turbidity is less than $100 \mathrm{FNU}$; Cp fluctuates between 0.4 and $0.5 ; \%$ WR ranges between 0.80 and $0.90 ; \mathrm{NaOH}$ solution is used to modify $\mathrm{pH}$, thus, showing a trend similar to BSw but less outstanding. Sedimentation performance in Tw shows a result independent of $\mathrm{pH}$ : the settling rate is approximately constant and equal to $3 \mathrm{~m} \cdot \mathrm{h}^{-1}$; residual turbidity is the highest at any $\mathrm{pH}$ (i.e., over $1000 \mathrm{FNU}$ ), thus, proving that salinity promotes the aggregation of colloidal solids; $\mathrm{Cp}$ and \% WR do not vary significantly with $\mathrm{pH}$ and show values similar to those resulting from sedimentation tests in BSw; $\mathrm{NaOH}$ consumption to regulate the $\mathrm{pH}$ is small, as Tw does not have a buffer effect. Finally, the sedimentation process in Sw is the poorest performing except for residual turbidity: actually, the mine tailings settling rate ranges between 0.5 and $3.6 \mathrm{~m} \cdot \mathrm{h}^{-1}$, decreasing with $\mathrm{pH}$; residual turbidity is the lowest (i.e., less than 20FNU), which agrees with previous works [37]; $\mathrm{Cp}$ and \% WR do not vary significantly, even if an inverse dependence on $\mathrm{pH}$ is noticed; the consumption of $\mathrm{NaOH}$, as already discussed for BSw and CHSw, increases with $\mathrm{pH}$. Interestingly, Tw represented the worst performing aqueous medium to conduct the sedimentation process, as tests carried out with it resulted in the highest residual turbidity coupled with a modest mine tailings settling rate.

Table 10 shows the comparison between experimental data resulting from the sedimentation tests conducted in CHSw, BSw, Tw, and Sw with those predicted by the RBFN model that were calibrated with experiments in ASw. It is noticed that there is a high variability between experimental and predicted results for sedimentation tests conducted in BSw, Tw, and Sw. It is highlighted that the effectiveness of CHSw is well predicted by the RBFN model, whereas the effectiveness of BSw is not affected by $\mathrm{pH}$, and those of Tw and Sw are overestimated, since the T for Tw was higher than that predicted, and $\mathrm{T}$ for Sw was lower than that predicted.

Table 10. Comparison between experimental data and those predicted by the Radial Basis Function Network model.

\begin{tabular}{|c|c|c|c|c|c|c|c|}
\hline & \multirow{2}{*}{\multicolumn{3}{|c|}{ Independent Parameters }} & \multicolumn{4}{|c|}{ Response Parameters } \\
\hline & & & & \multicolumn{2}{|c|}{ Settling Rate $\left(\mathrm{m} \cdot \mathrm{h}^{-1}\right)$} & \multicolumn{2}{|c|}{ Turbidity [FNU] } \\
\hline & Ca mg $\cdot \mathrm{L}^{-1}$ & Mg mg $\cdot \mathrm{L}^{-1}$ & $\mathrm{pH}$ & Experimental Data & RBFN Data & Experimental Data & RBFN Data \\
\hline \multirow{3}{*}{ CHSw } & \multirow{3}{*}{263} & \multirow{3}{*}{648} & 9.3 & 4.207 & 3.19 & 105.75 & 89.1 \\
\hline & & & 10.5 & 5.344 & 4.76 & 51.375 & 44.25 \\
\hline & & & 11.5 & 2.673 & 2.28 & 18.142 & 25.3 \\
\hline \multirow{3}{*}{ BSw } & \multirow{3}{*}{5.8} & \multirow{3}{*}{284} & 9.3 & 5.432 & 3.5 & 126 & 186 \\
\hline & & & 10.5 & 5.659 & 5.35 & 129 & 145 \\
\hline & & & 11.5 & 5.420 & 2.84 & 100 & 62.54 \\
\hline \multirow{3}{*}{ Tw } & \multirow{3}{*}{75} & \multirow{3}{*}{26} & 9.3 & 3.375 & 5.68 & 1000 & 213.34 \\
\hline & & & 10.5 & 3.264 & 5.73 & 1000 & 209.58 \\
\hline & & & 11.5 & 3.072 & 4.08 & 1000 & 103.92 \\
\hline \multirow{3}{*}{ Sw } & \multirow{3}{*}{395} & \multirow{3}{*}{1270} & 9.3 & 3.552 & 6.95 & 15 & 90.98 \\
\hline & & & 10.5 & 1.165 & 5.96 & 18 & 55.77 \\
\hline & & & 11.5 & 0.553 & 0.73 & 14.7 & 37.51 \\
\hline
\end{tabular}

\section{Conclusions}

This work has investigated, by the use of RBFN methodology, the best chemical composition of partial desalinated seawater, in terms of $\mathrm{Ca}^{2+}$ and $\mathrm{Mg}^{2+}$ concentration, to optimize the sedimentation process performance. It was found that the optimal ranges of $\mathrm{Ca}^{2+}$ and $\mathrm{Mg}^{2+}$ concentration are respectively as follows: $169-338$ and $0-130 \mathrm{mg} \cdot \mathrm{L}^{-1}$ at $\mathrm{pH} 9.3$; (ii) $0-21$ and $400-741 \mathrm{mg} \cdot \mathrm{L}^{-1}$ at $\mathrm{pH}$ 10.5; (iii) $377-418$ and $703-849 \mathrm{mg} \cdot \mathrm{L}^{-1}$ at $\mathrm{pH} 11.5$. Furthermore, this study has proved that partial desalinized seawater is more efficient than raw seawater as well as tap water in conducting the 
sedimentation process for mining purposes. Such results can have a highly positive impact on the environment without depressing the economy, as mining factories could stop using freshwater as well as desalinated seawater to process ores, thus, reducing significantly the environmental as well as financial costs. Partial desalinized seawater needs less production costs than totally desalinated water, even less if pretreated seawater by biomineralization methods is preferred to chemical. Moreover, a partial desalinized water is better performing than seawater for the sedimentation process and causes less damages to pipelines and other devices used for mining purposes. Finally, partially desalinated water could replace completely freshwater currently used by mining factories, thus, preserving this strategic resource.

Author Contributions: G.V. performed the experiments, modeling, analysis of results and writing this article; D.A. participated in devising the presented idea and writing; R.J. analyzed the results of sedimentation assays and writing; A.P. participated in writing this article and editing the English language; M.R. participated in the design of the trials, reviewing this article, and funding acquisition; L.A.C. participated in project administration, modeling, funding acquisition, designing the experiments, and writing this article. All authors have read and agreed to the published version of the manuscript.

Funding: The authors thanks the support of ANID through Anillo-Grant no. ACM 170005.

Conflicts of Interest: The authors declare no conflict of interest.

\section{References}

1. Cruz, C.; Reyes, A.; Jeldres, R.I.; Cisternas, L.A.; Kraslawski, A. Using Partial Desalination Treatment To Improve the Recovery of Copper and Molybdenum Minerals in the Chilean Mining Industry. Ind. Eng. Chem. Res. 2019, 58, 8915-8922. [CrossRef]

2. Hoekstra, A.Y.; Mekonnen, M.M.; Chapagain, A.K.; Mathews, R.E.; Richter, B.D. Global Monthly Water Scarcity: Blue Water Footprints versus Blue Water Availability. PLoS ONE 2012, 7, 1-9. [CrossRef] [PubMed]

3. Cisternas, L.A.; Gálvez, E.D. The use of seawater in mining. Miner. Process. Extr. Metall. Rev. 2018, 39. [CrossRef]

4. Herrera-León, S.; Cruz, C.; Kraslawski, A.; Cisternas, L.A. Current situation and major challenges of desalination in Chile. Desalin. Water Treat. 2019, 171, 93-104. [CrossRef]

5. Li, Y.; Li, W.; Xiao, Q.; He, N.; Ren, Z.; Lartey, C.; Gerson, A. The Influence of Common Monovalent and Divalent Chlorides on Chalcopyrite Flotation. Minerals 2017, 7, 111. [CrossRef]

6. Lucay, F.; Cisternas, L.A.; Gálvez, E.; Lopez-Valdivieso, A. Study of the natural floatability of molybdenite fines in saline solutions and effect of gypsum precipitation. Miner. Metall. Process. 2015, 32, 203-208. [CrossRef]

7. Jeldres, R.I.; Arancibia-Bravo, M.P.; Reyes, A.; Aguirre, C.E.; Cortes, L.; Cisternas, L.A. The impact of seawater with calcium and magnesium removal for the flotation of copper-molybdenum sulphide ores. Miner. Eng. 2017, 109, 10-13. [CrossRef]

8. Castro, S. Physico-chemical factors in flotation of $\mathrm{Cu}-\mathrm{Mo}-\mathrm{Fe}$ ores with seawater: A critical review. Physicochem. Probl. Miner. Process. 2018, 54, 1223-1236.

9. Wang, B.; Peng, Y.; Vink, S. Effect of saline water on the flotation of fine and coarse coal particles in the presence of clay minerals. Miner. Eng. 2014, 66, 145-151. [CrossRef]

10. Jeldres, R.I.; Forbes, L.; Cisternas, L.A. Effect of Seawater on Sulfide Ore Flotation: A Review. Miner. Process. Extr. Metall. Rev. 2016, 37, 369-384. [CrossRef]

11. Israelachvili, J. Intermolecular and Surface Forces, 3rd ed.; Elsevier: Santa Barbara, CA, USA, 2011; ISBN 9780123919274.

12. Benn, F.A.; Fawell, P.D.; Halewood, J.; Austin, P.J.; Costine, A.D.; Jones, W.G.; Francis, N.S.; Druett, D.C.; Lester, D. Sedimentation and consolidation of different density aggregates formed by polymer-bridging flocculation. Chem. Eng. Sci. 2018, 184, 111-125. [CrossRef]

13. Witham, M.I.; Grabsch, A.F.; Owen, A.T.; Fawell, P.D. The effect of cations on the activity of anionic polyacrylamide flocculant solutions. Int. J. Miner. Process. 2012, 114-117, 51-62. [CrossRef]

14. Lee, B.J.; Schlautman, M.A.; Toorman, E.; Fettweis, M. Competition between kaolinite flocculation and stabilization in divalent cation solutions dosed with anionic polyacrylamides. Water Res. 2012, 46, 5696-5706. [CrossRef] [PubMed]

15. Ramos, J.; Leiva, W.H.; Castillo, C.; Ihle, C.F.; Fawell, P.D.; Jeldres, R.I. Seawater flocculation of clay-based mining tailings: Impact of calcium and magnesium precipitation. Miner. Eng. 2020, 154, 106417. [CrossRef] 
16. Jeldres, M.; Piceros, E.C.; Toro, N.; Robles, P.; Nieto, S.; Quezada, G.R.; Jeldres, R.I. Enhancing the sedimentation of clay-based tailings in seawater by magnesium removal treatment. Sep. Purif. Technol. 2020, 242, 116762. [CrossRef]

17. Cruz, C.; Ramos, J.; Robles, P.; Leiva, W.H.; Jeldres, R.I.; Cisternas, L.A. Partial seawater desalination treatment for improving chalcopyrite floatability and tailing flocculation with clay content. Miner. Eng. 2020, 151, 106307. [CrossRef]

18. Arias, D.; Villca, G.; Pánico, A.; Cisternas, L.A.; Jeldres, R.I.; González-Benito, G.; Rivas, M. Partial desalination of seawater for mining processes through a fluidized bed bioreactor filled with immobilized cells of Bacillus subtilis LN8B. Desalination 2020, 482, 114388. [CrossRef]

19. Aminian, A. Prediction of temperature elevation for seawater in multi-stage flash desalination plants using radial basis function neural network. Chem. Eng. J. 2010, 162, 552-556. [CrossRef]

20. Mobin, M.; Shabnam, H. Corrosion Behavior of Mild Steel and SS 304L in Presence of Dissolved Nickel Under Aerated and Deaerated Conditions. Mater. Res. 2011, 14, 524-531. [CrossRef]

21. Arias, D.; Cisternas, L.A.; Miranda, C.; Rivas, M. Bioprospecting of Ureolytic Bacteria From Laguna Salada for Biomineralization Applications. Front. Bioeng. Biotechnol. 2019, 6, 209. [CrossRef]

22. Herbort, S.; Wöhler, C. An introduction to image-based 3D surface reconstruction and a survey of photometric stereo methods. 3D Res. 2011, 2. [CrossRef]

23. Hagan, M.T.; Demuth, H.B.; Beale, M.H.; De Jess, O. Radial Basis Network. In Neural Network Design; Martin Hagan: Stillwate, OK, USA, 2014; p. 1012, ISBN 0971732116.

24. Xie, Y.; Xing, Y. A prediction method for the wax deposition rate based on a radial basis function neural network. Petroleum 2017, 3, 237-241. [CrossRef]

25. Lucay, F.A.; Sales-Cruz, M.; Gálvez, E.D.; Cisternas, L.A. Modeling of the Complex Behavior through an Improved Response Surface Methodology. Miner. Process. Extr. Metall. Rev. 2020, 41, 1-27. [CrossRef]

26. Livingstone, D.J. (Ed.) Artificial Neural Networks; Humana Press: Totowa, NJ, USA, 2009; ISBN 978-1-60327-101-1.

27. Jeldres, R.I.; Piceros, E.C.; Leiva, W.H.; Toledo, P.G.; Herrera, N. Viscoelasticity and yielding properties of flocculated kaolinite sediments in saline water. Colloids Surfaces A Physicochem. Eng. Asp. 2017, 529, 1009-1015. [CrossRef]

28. Cisternas, L.A.; Lucay, F.A.; Botero, Y.L. Trends in Modeling, Design, and Optimization of Multiphase Systems in Minerals Processing. Minerals 2019, 10, 22. [CrossRef]

29. Belessiotis, V.; Kalogirou, S.; Delyannis, E. Water, the Raw Material for Desalination. In Thermal Solar Desalination; Academic Press: Cambridge, MA, USA, 2016; pp. 21-102, ISBN 978-0-12-809656-7.

30. Mpofu, P.; Addai-Mensah, J.; Ralston, J. Influence of hydrolyzable metal ions on the interfacial chemistry, particle interactions, and dewatering behavior of kaolinite dispersions. J. Colloid Interface Sci. 2003, 261, 349-359. [CrossRef]

31. Jeldres, M.; Piceros, E.; Robles, P.A.; Toro, N.; Jeldres, R.I. Viscoelasticity of quartz and kaolin slurries in seawater: Importance of magnesium precipitates. Metals 2019, 9, 1120. [CrossRef]

32. Kapp, E.M. The precipitation of calcium and magnesium from sea water by sodium hydroxide. Biol. Bull. 1928, 55, 453-458. [CrossRef]

33. Yang, Z.; Zhao, H. A New RBF Reflection Model for Shape from Shading. 3D Res. 2017, 8, 33. [CrossRef]

34. Al-Haik, M.S.; Hussaini, M.Y.; Rogan, C.S. Artificial intelligence techniques in simulation of viscoplasticity of polymeric composites. Polym. Compos. 2009, 30, 1701-1708. [CrossRef]

35. Charte, F.; Romero, I.; Pérez-Godoy, M.D.; Rivera, A.J.; Castro, E. Comparative analysis of data mining and response surface methodology predictive models for enzymatic hydrolysis of pretreated olive tree biomass. Comput. Chem. Eng. 2017, 101, 23-30. [CrossRef]

36. Arias, D.; Cisternas, L.A.; Rivas, M. Biomineralization of calcium and magnesium crystals from seawater by halotolerant bacteria isolated from Atacama Salar (Chile). Desalination 2017, 405. [CrossRef]

37. Jeldres, R.I.; Jeldres, M.; MacIver, M.R.; Pawlik, M.; Robles, P.; Toro, N. Analysis of kaolin flocculation in seawater by optical backscattering measurements: Effect of flocculant management and liquor conditions. Minerals 2020, 10, 317. [CrossRef]

(C) 2020 by the authors. Licensee MDPI, Basel, Switzerland. This article is an open access article distributed under the terms and conditions of the Creative Commons Attribution (CC BY) license (http://creativecommons.org/licenses/by/4.0/). 